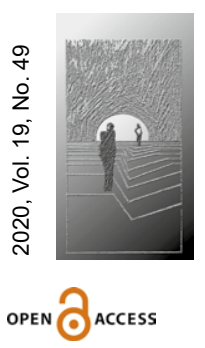

Józef Majewski

http://orcid.org/0000-0001-9617-6454

Uniwersytet Gdański

Wydział Nauk Społecznych

jozef.majewski@ug.edu.pl

DOI: $10.35765 / h w .1823$

\title{
Autentyczna kultura spotkania. Media a współczesny kryzys rodziny według papieża Franciszka
}

\section{STRESZCZENIE}

CEL NAUKOWY: Celem artykułu jest odpowiedź na pytanie, jak Franciszek widzi współczesny kryzys rodziny w perspektywie funkcjonowania mediów, środków komunikacji społecznej.

PROBLEM I METODY BADAWCZE: Za pomocą krytyczno-ilościowej analizy wybranych źródeł, uzupełnionej o analizę porównawczą, zamierzam odpowiedzieć na pytanie postawione powyżej.

PROCES WYWODU: Artykuł składa się z pięciu części: 1) „Wprowadzenie” - zarysowanie problemu; 2) „Kryzys rodziny?” - krytyczne spojrzenie na socjologiczne stanowisko, według którego współczesne zmiany instytucji rodziny nie mają charakteru kryzysu; rozumienie kryzysu przez Franciszka; 3) „Mediatyzacja rodziny” - o trudnościach z wyważeniem odpowiedzialności mediów za kryzys rodziny; stanowisko Franciszka w tym względzie; 4) Model komunikacji - komunikacyjne - według Franciszka - „pokrewieństwo” między rodziną i mediami; w jakim sensie - zdaniem Franciszka - współczesne media stanowią problem i zagrożenie dla instytucji rodziny; 5) Zakończenie (podsumowanie i wnioski).

WYNIKI ANALIZY NAUKOWEJ: Z dotychczasowego nauczania Franciszka o środkach komunikacji społecznej i rodzinie wynika, że media nie tyle są źródłem kryzysu rodziny, ile poświadczają jego istnienie, a przy tym czynią to jednostronnie, skupiając się na kryzysowej sytuacji rodziny. Nie znaczy to, że media nie mogą być czy nie są dla rodziny zagrożeniem, niebezpieczeństwem i problemem.

WNIOSKI, INNOWACJE, REKOMENDACJE: Jak do tej pory - i wedle wiedzy autora - w literaturze przedmiotu brakuje zaprezentowanej interpretacji nauczania Franciszka.

$\rightarrow$ SŁOWA KLUCZOWE: RODZINA, KRYZYS RODZINY, MEDIATYZACJA, MEDIA, KOMUNIKACJA, MODEL KOMUNIKACJI, KULTURA SPOTKANIA 


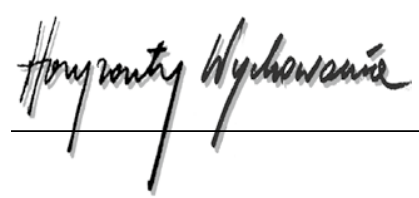

\begin{abstract}
The Authentic Culture of Encounter. The Media and the Contemporary Crisis of the Family According to Pope Francis
\end{abstract}

RESEARCH OBJECTIVE: An answer to the question of how Francis sees the contemporary crisis of the family in the perspective of the functioning of the media - means of social communication.

THE RESEARCH PROBLEM AND METHODS: I intend to answer the question posed above with the help of critical-quantitative analysis of selected sources, complemented with comparative analysis.

THE PROCESS OF ARGUMENTATION: The article comprises five parts: 1. "Introduction" - where the problem is sketched. 2. "Crisis of the Family?" - presenting a critical look at the sociological standpoint according to which the contemporary changes to the institution of the family are not marked by the features of a crisis, and Francis' understanding of a crisis. 3. "Mediatization of the Family" - discussing difficulties with the balancing of the media's responsibility for the crisis of the family and Francis' related standpoint. 4. "Model of Communication" - presenting communication-related "relatedness" - according to Francis - between the family and the media and discussing in what sense - according to Francis - the contemporary media are a problem and a threat to the institution of the family; 5 . "Conclusion" - containing a summary and conclusions.

RESEARCH RESULTS: It results from Francis' teaching about means of social communication and family that the media are not so much the source of the crisis of the family, as confirm its existence, doing it unilaterally, focusing on the crisis situation of the family. This does not mean that the media cannot be or are not a threat to the family, a danger and a problem.

CONCLUSIONS, INNOVATIONS, AND RECOMMENDATIONS: According to the author's best knowledge, interpretation of Francis' teaching has not yet been presented in source literature.

$\rightarrow$ KEYWORDS: FAMILY, THE CRISIS OF THE FAMILY, MEDIATIZATION, MEDIA, COMMUNICATION, MODEL OF COMMUNICATION, CULTURE OF ENCOUNTER

\title{
1. Wprowadzenie
}

Franciszek w programowym dokumencie swojego pontyfikatu - w adhortacji apostolskiej Evangelii gaudium - słowem „kryzys” (włoskie „crisi”) posłużył się dziesięć razy. Papież wspomina tam o kryzysie finansowym, kryzysie antropologicznym, kryzysie ideologii, kryzysie tożsamości, kryzysie zaangażowania i więzi wspólnotowych (Franciszek, 2013a $)^{1}$. Pisze także o kryzysie rodziny:

${ }^{1}$ W wypowiedziach Franciszka znajdziemy jeszcze np. kryzys ekonomiczny, kryzys wzorców społecznych, kryzys instytucjonalny czy kryzys migracyjny (zob. np. Franciszek, 2017). 
Rodzina przechodzi głęboki kryzys kulturowy, podobnie jak wszystkie wspólnoty oraz więzi społeczne. W przypadku rodziny kruchość więzi staje się szczególnie poważna, ponieważ chodzi o podstawową komórkę społeczeństwa, o miejsce, gdzie człowiek uczy się współżycia w różnorodności i przynależności do innych oraz gdzie rodzice przekazują dzieciom wiarę. (...) Postmodernistyczny i zglobalizowany indywidualizm sprzyja stylowi życia osłabiającego wzrost i stabilność więzi między osobami i deformuje więzi rodzinne (Franciszek, 2013b, nr 66-67).

W niniejszych rozważaniach interesuje mnie to, co Franciszek ma do powiedzenia o kryzysie rodziny, ale wyłącznie w relacji tego kryzysu do funkcjonowania mediów, środków komunikacji społecznej. W takiej perspektywie znamienne jest, że w Evangelii gaudium temat mediów nie jest wyeksponowany w kontekście kryzysu rodziny. I w ogóle w papieskim dokumencie terminologii i problematyki medialnej raczej niewiele: słowo „media” pojawia się w nim dwa razy, „mezzi di comunicazione sociale” - pięć razy, a takich terminów jak „Internet” czy „social media” - w ogóle brak (Franciszek, 2013a). Jak zatem w oczach Franciszka wygląda relacja między mediami a współczesnym kryzysem rodziny?

\section{Kryzys rodziny?}

W środowisku nauk społecznych padają dziś różne odpowiedzi na pytanie, czy współcześnie w świecie Zachodu mamy do czynienia z kryzysem rodziny - z kryzysem instytucji rodziny. Część socjolożek/socjologów przekonuje, że wielkie czy wręcz rewolucyjne zmiany i przemiany, jakim podlega w naszych czasach ta instytucja, nie mają nic (lub prawie nic) wspólnego z kryzysem². Że w istocie - jak pisze Tomasz Szlendak, jeden $\mathrm{z}$ przedstawicieli tego stanowiska -

to, co się dzisiaj dzieje z rodziną, to nie kryzys, ponieważ zgodnie z definicją kryzys to prob-
lem nierozwiązywalny środkami wewnętrznymi. Inaczej mówiąc to taki kłopot, krach czy ka-
tastrofa, którą da się rozwiązać ku powszechnej szczęśliwości jedynie z zewnątrz. Czy z taką
sytuacją mamy do czynienia w zakresie życia rodzinnego? Raczej nie. To po prostu zmiany.
Może bardzo radykalne, może rzeczywiście rewolucyjne, ale tylko zmiany, które dają się za-
mykać w trendach obserwowanych przez socjologów. Postrzeganie tych trendów w katego-
riach schyłku, upadku, zmierzchu i właśnie kryzysu wynika z przyjęcia pewnych założeń co
do „natury” albo „tradycji” rodzinnej, jedynej właściwej czy dobrej (Szlendak, 2010, s. 395).

W stanowisku Szlendaka problematyczne zdaje się przede wszystkim pojmowanie tego, czym jest kryzys w ogóle. Chociaż tej zasadniczej kwestii nie poświęcił on w swoim opracowaniu zbyt wiele uwagi i (w konsekwencji?) jego wywód nie jest w pełni jasny, to klarowne jest przynajmniej to, że w nieuzasadniony sposób przeniósł on klasyczne socjologiczno-psychologiczne pojmowanie kryzysu w rodzinie (nieuzdrawialny od wewnątrz

${ }^{2}$ Stanowiska w tej sprawie prezentuje Tomasz Szlendak w rozdziale w podrozdziale Tak zwany kryzys rodziny w podręczniku akademickim Socjologia rodziny (Szlendak, 2010, s. 363-403). 


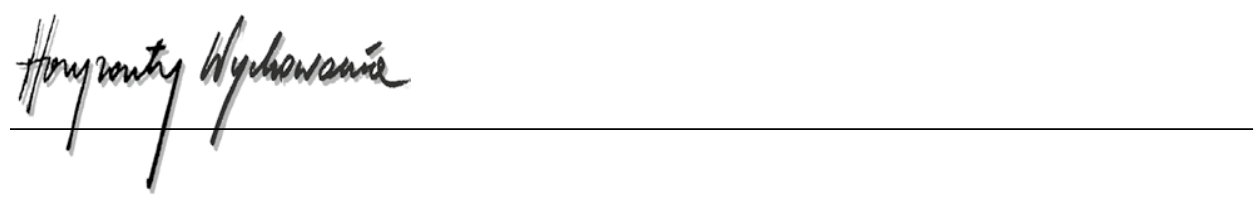

stan niekorzystnej sytuacji) na szerokie, globalizujące się złożone, wieloaspektowe i wielopłaszczyznowe zjawiska dynamicznych i głębokich transformacji społeczno-kulturowych i egzystencjalno-etycznych, którym podlega dziś ludzki świat. Ponadto zdaniem autora Socjologii rodziny kryzys to radykalne zmiany o charakterze wyłączenie negatywnym - to zło, które zatruwa i niszczy. Można jednak pytać, czy ujęcie Szlendaka nie jest jednostronne, upraszczające złożoną i skomplikowaną materię życia społecznego.

Różni autorzy proponują inne rozumienia, czym jest kryzys (zob. Husserl, 1993; Kasper, 2001; Koselleck, 2015; Gielarowski, 2016; Skuczyński, 2018), choćby takie, gdzie może on mieć oblicze nie tylko „ciemne”, ale i „jasne”, gdzie kryzys może być zarówno zagrożeniem, niszczeniem możliwości i burzeniem, jak też szansą, nowymi możliwościami i budowaniem. Gdzie z kryzysem można sobie radzić (bardziej lub mniej skutecznie) od wewnątrz, poprzez radykalną duchową, intelektualną, indywidualną, społeczną czy religijną mobilizację, źródłowo opierającą się na nadziei na przezwyciężenie trudności, bez oczekiwania czy konieczności ingerencji z zewnątrz. Taką wykładnię kryzysu można znaleźć np. w wypowiedziach Franciszka, choćby w przemówieniu do szefów państw i rządów Unii Europejskiej z okazji 60. rocznicy podpisania traktatów rzymskich:

nasz czas jest zdominowany przez pojęcie kryzysu. Istnieje (...) wiele kryzysów, które skrywają strach i głębokie zagubienie współczesnego człowieka, domagającego się nowej hermeneutyki na przyszłość. Jednakże termin „kryzys” nie ma sam w sobie znaczenia negatywnego. Oznacza nie tylko złe czasy, które trzeba pokonać. Słowo kryzys ma swoje korzenie w greckim czasowniku (...) kpívw (...), co oznacza „dochodzenie”, „przemyślenie”, „osądzenie”. Zatem nasze czasy są okresem rozeznawania, zachęcającym nas do rozważenia tego, co istotne, i budowania na nim: jest to zatem czas wyzwań i szans (Franciszek, 2017) ${ }^{3}$.

W przywołanym tu kontekście nauk społecznych wypada podkreślić, że cztery lata wcześniej w Evangelii gaudium papież skonstatował, iż w rozumieniu i ocenie współczesnej sytuacji społeczeństw i kultur spojrzenie czysto socjologiczne nie wystarcza:

Dzisiaj zwykło się mówić o „przesadzie diagnostycznej”, której nie zawsze towarzyszą rozstrzygające decyzje, możliwe do zastosowania. Z drugiej strony nie służy nam także spojrzenie czysto socjologiczne, które swą metodologią chce ogarnąć całą rzeczywistość w sposób tylko hipotetycznie neutralny i aseptyczny (Franciszek, 2013b, nr 50).

${ }^{3}$ W podobnym duchu o kryzysie mówił w 2001 r., a dwa lata później pisał na łamach brytyjskiego tygodnika „The Tablet” kard. Walter Kasper, ówczesny przewodniczący Papieskiej Rady Popierania Jedności Chrześcijan. W 2001 r. w kontekście kryzysu ruchu ekumenicznego powiedział: „terminu «kryzys» nie należy rozumieć jednostronnie, w negatywnym sensie załamania się lub upadku tego, co zostało zbudowane (...) - jakby było to już bez znaczenia. Termin «kryzys» rozumiem tu w źródłowym greckim sensie jako sytuację, w której sprawy są nierozstrzygnięte i pozostają na ostrzu noża. W istocie stan ten może być bądź pozytywny, bądź negatywny. Obie możliwości wchodzą w grę. Z sytuacją kryzysu mamy do czynienia wtedy, gdy dotychczasowe drogi dobiegają kresu, lecz otwiera się miejsce dla nowych możliwości. Toteż sytuacja kryzysu przedstawia się jako wyzwanie i czas decyzji" (Kasper, 2001; por. Kasper, 2003, s. 23). Zagadnienia językowo-etymologiczne słowa „kryzys” szeroko omawia Koselleck, 2006, s. 358-367. 
Tymczasem spojrzenie papieża - jak oznajmił w tym samym dokumencie - „idzie raczej po linii ewangelicznego rozeznania" (Franciszek, 2013b, nr 50).

\section{Mediatyzacja rodziny}

Programowy dokument obecnego pontyfikatu raczej nie epatuje terminologią i tematyką medialną. Podobnie ma się sytuacja w słynnej adhortacji Amoris laetitia, którą Franciszek w całości poświęcił rodzinie: łacińskie słowo discrimen („kryzys”) pojawia się tu 20 razy, gdy tymczasem instrumenta communicationis (,środki komunikacji”, „media”) - raz, Interrete („Internet”) - raz, a media socialia („media społecznościowe”) ani razu (Franciszek, 2016a).

W sześciu orędziach Franciszka na doroczny styczniowy Światowy Dzień Komunikacji Społecznej (2014-2019) „media”, „Internet” i „media społecznościowe”, co oczywiste, stanowią kanwę rozważań, z kolei słowo „rodzina” pojawia się w nich łącznie 38 razy, podczas gdy słowo „kryzys” - tylko raz, w orędziu z 2015 r., którego tematem jest rodzina.

Z kolei w przemówieniu Franciszka wygłoszonym do rodzin przy okazji Światowego Spotkania Rodzin w Filadelfii (22-27 września 2015 r., USA) terminologia medialna w ogóle nie występuje, nie występuje także słowo „kryzys”. Trzy lata później, podczas Światowego Dnia Rodzin w Dublinie (25-26 sierpnia 2018, Irlandia) papież w przemówieniach raz przywołał „Internet”, a pięć razy „social media”, ani razu jednak nie posłużył się terminem „kryzys” (Franciszek, 2018a) ${ }^{4}$.

Skromność terminologii medialnej w wypowiedziach Franciszka o kryzysie rodziny, jak też skromność terminologii kryzysowej w jego dokumentach o mediach, daje do myślenia, ale nie znaczy, że u papieża nie ma związku tego kryzysu z mediami. Otóż, w jakiś sposób są one u niego powiązane, co chyba najwyraźniej doszło do głosu w jego drugim orędziu na Światowy Dzień Komunikacji Społecznej - pt. Komunikacja rodziny: uprzywilejowane środowisko spotkania w bezinteresownej miłości. Franciszek pisze tam: rodzina

jest (...) wspólnotą, która potrafi pomagać, świętować i owocować. W tym sensie możliwe jest przywrócenie spojrzenia zdolnego, by uznać, że rodzina jest nadal wielkim bogactwem, a nie tylko problemem lub instytucją przeżywającą kryzys . Media [podkreślenie moje J.M.] często skłonne są przedstawiać rodzinę, jak gdyby była modelem abstrakcyjnym, który można zaakceptować lub odrzucić, bronić albo atakować, a nie konkretną rzeczywistością, w której się żyje. Albo jakby była jakąś ideologią jednego wymierzoną w ideologię kogoś innego, a nie miejscem, w którym wszyscy uczymy się, co znaczy komunikować w miłości otrzymanej i danej (Franciszek, 2015).

Papież, patrząc na relację między kryzysem rodziny a mediami, daje do zrozumienia, że media mają związek z tym kryzysem, ale w materii tej wypowiada się ostrożnie,

${ }^{4}$ Dodajmy na koniec tych papieskich statystyk, że oficjalna watykańska wyszukiwarka przeszukująca internetowe biblioteki Stolicy Apostolskiej, zapytana o „la crisi della famiglia”, wygenerowała 24 linki. Znaczące jednak, że we wskazanych dokumentach w ogóle nie pojawiają się takie terminy jak „media”, „Internet” czy „media społecznościowe”. 


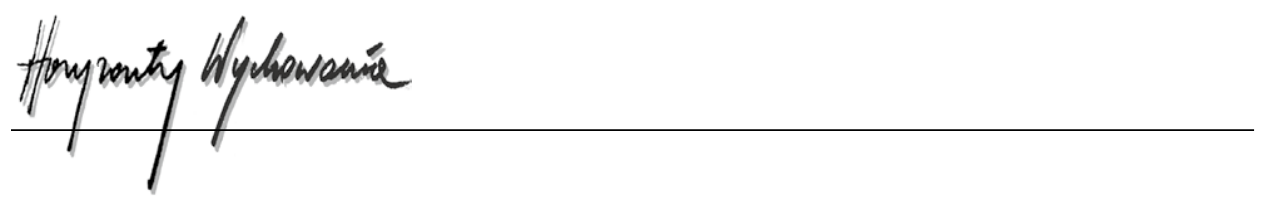

zresztą zazwyczaj podobnie postępują badacze spod znaku nauk społecznych ${ }^{5}$. Gwałtowny i dynamiczny rozwój technologii medialno-internetowych, odgrywający główną rolę w transformacjach społeczeństwa Zachodu, dokonuje się od zaledwie kilku dekad, tak że badania tych zjawisk i procesów, które dziś określa się mianem mediatyzacji, wciąż mają postać raczej prowizoryczną, fragmentaryczną, rudymentarną. Mówiąc ściślej, mediatyzację można rozumieć jako szeroką, złożoną, zróżnicowaną i wielostronną transformację wszystkich sfer życia społeczno-kulturowego pod wpływem stale ewoluujących środków medialno-komunikacyjnych i na wzór charakterystycznych dla nich sposobów działania (zob. Hjarvard, 2013; Dróżdż i Smoleń, 2015; Lisowska-Magdziarz, 2015; Driessens, Bolin, Hepp i Hjarvard, 2017).

Środki komunikacji społecznej oczywiście zawsze w ten czy inny sposób determinowały życie społeczne i kulturę, tyle że zmiany medialno-komunikacyjne w przeszłości przebiegały w wielkich interwałach czasowych, o rozmiarach epok, w rezultacie niejako starczyło czasu, by w większym lub mniejszym stopniu można było za nimi percepcyjnie, egzystencjalnie, społecznie, etycznie czy religijnie nadążyć. Tymczasem dzisiaj interwały te skurczyły się do rozmiarów lat, nawet miesięcy, zmiany nachodzą na siebie, wzajemnie przepychają i napędzają, determinując transformacje społeczno-kulturowe, za którymi pod wieloma względami - także naukowo-badawczymi - trudno czy wręcz nie sposób nadążyć (Mencwell, 2002).

Na podstawie wypowiedzi Franciszka można wysnuć wniosek, że zgodziłby się on z Bernadette Bawin-Legros, iż w dziedzinie życia rodzinnego w naszych czasach jesteśmy wciągnięci w wiry (przynajmniej) „trzech wielkich transformacji” („three major transformations"): 1) transformacja punktów odniesienia: indywidualizacja; 2) transformacja norm: prywatyzacja; 3) transformacja modeli: pluralizacja (Bawin-Legros, 2001) ${ }^{6}$. To, że w społeczeństwach Zachodu dokonuje się antropologiczno-kulturowa indywidualizacja,

\footnotetext{
${ }^{5}$ W Socjologii rodziny Szlendaka ze świecą szukać mediów, Internetu czy mediów społecznościowych. Nie lepiej ma się sytuacja w takich studiach nad rodziną jak np.: Kocik, 2006; Kawula, 2006; Treas, Scott i Richards 2017.

${ }^{6}$ Zwięźle stanowisko Bawin-Legros przedstawił Szlendak: „1. Indy widualizacja w zakresie punktów odniesienia [«A transformation of references: individualization»]. Ludzie przestali definiować siebie i swoje rodziny w odniesieniu do grup, a zaczęli się definiować w odniesieniu do siebie samych, swoich potrzeb i ambicji. Jednostka stała się (dopiero) dzisiaj podstawową składową społeczeństwa. Jej własne wybory przenoszą się na procesy społeczne poprzez mechanizm działania zbiorowego. (...) 2. Prywatyzacja w zakresie norm ["A transformation of norms: privatization»]. Jakakolwiek norma społeczna, zwłaszcza w jakiejś ostrzejszej formie albo silniej sankcjonowana, wydaje się ludziom ingerencją w ich prywatne życie oraz intymne wybory, zaburza ich autonomię. Ingerencja zaś w życie rodzinne czy uczuciowe jest uznawana za wtrącanie się najgorsze z możliwych. Życie prywatne jest najważniejszą składową tożsamości w społeczeństwach zachodnich. (...) 3. Pluralizacja w zakresie modeli życia ["A transformation of models: pluralization»]. Pojawia się dzisiaj wiele dostępnych i możliwych do realizowania modeli związku i rodziny, co jest bezpośrednią konsekwencją (...) indywidualizacji i prywatyzacji. To właśnie rozplenienie się rozmaitych alternatywnych modeli rodziny jest najczęściej opisywanym efektem przemian w zakresie stylu życia. Te z kolei przemiany biorą się z uznania praw ludzi do samostanowienia w zakresie uczuć, miłości i seksualności” (Szlendak, 2010, s. 400-401).
} 
prywatyzacja i pluralizacja, jest faktem, ale jaki udział w tych wielkich (i innych) transformacjach mają media, w jakim stopniu o tych transformacjach decydują środki komunikacji społecznej - co do tego znajdujemy się na początku badawczej drogi. (W studium samej Bawin-Legros media nie odgrywają żadnej roli ${ }^{7}$.) Badania i lepsze zrozumienie zjawiska mediatyzacji społeczeństw, w tym mediatyzacji współczesnej rodziny, wciąż są przed nami. Więcej tu niepewności niż pewności.

\section{Model komunikacji}

W obliczu (zarówno) niepewności (jak i pewności) co do roli, jaką mediatyzacja życia rodzinnego odgrywa w kryzysie rodziny, Franciszek zdaje się preferować język i oceny ostrożne, z charakterystyczną dla siebie, można powiedzieć, hermeneutyką optymizmu krytycznego, w wypadku problematyki niniejszych rozważań - akcentowania pozytywnych aspektów działania mediów, ale bez zamykania oczu na aspekty negatywne.

Franciszek dostrzega między rodziną a mediami swoiste pokrewieństwo: oba te „byty” mają charakter komunikacyjny i społeczny - są przestrzenią międzyludzkiej komunikacji i mają komunikacji między ludźmi służyć, chociaż pod tym względem nie ma mediów idealnych, niemniej jednak - jak pisze papież - „Nie ma [też] rodziny idealnej, ale nie wolno nam bać się niedoskonałości, kruchości, a nawet konfliktów; trzeba się nauczyć stawiania im czoła w sposób konstruktywny" (Franciszek, 2015). W refleksji na temat mediów Franciszek idzie po linii komunikacyjnego przełomu, jakim w nauczaniu Kościoła w tej dziedzinie okazał się Sobór Watykański II, konkretnie zaś Decretum de instrumentis communicationis socialis „Inter mirifica” (Sobór Watykański II, 1963), czyli Dekret o środkach komunikacji społecznej „Inter mirifica”. Wypada podkreślić, że tytuł tego dokumentu zawiera właśnie „komunikację społeczną”, a nie „społeczny przekaz”| „społeczne przekazywanie” - jak błędnie głoszą oba oficjalne polskie przekłady dekretu: Dekret o środkach społecznego przekazywania myśli (Sobór Watykański II, 1968); Dekret o środkach społecznego przekazu (Sobór Watykański II, 2002). Na Soborze w dziedzinie mediów zdecydowano o rezygnacji z języka „przekazu” na rzecz języka „komunikowania”. Informował o tym u nas już ks. Andrzej Maria Deskur, sekretarz Sekretariatu Przygotowawczego Soboru dla Prasy i Widowisk:

Nieosobowy termin diffusio [,przekaz” - J.M.], użyty jeszcze w encyklice Miranda prorsus [Piusa XII, 1957 r. - J.M.], został zastąpiony terminem communicatio, w znaczeniu wymiany o charakterze duchowym, wśród osób wolnych i rozumnych. Jednocześnie słowa massa, multitudo zostały sprecyzowane przez słowo societas, przy włączeniu społecznej nauki Kościoła (Deskur, 1968, s. 75; por. Eilers, 1993, s. 57n.; Eilers, 2016, s. 103-110) ${ }^{8}$.

\footnotetext{
${ }^{7}$ W przywołanym studium Bawin-Legros terminologia medialna pojawia się raz, na s. 50.

8 „Niestety, polscy tłumacze i wydawcy dokumentów soborowych zupełnie zignorowali zarówno treść Inter mirifica, jak i wprowadzenie ks. Andrzeja Marii Deskura i konsekwentnie utrwalili istniejące po dzień dzisiejszy określenia: «masowy przekaz», «środki przekazu». Co więcej, korektura nie
} 


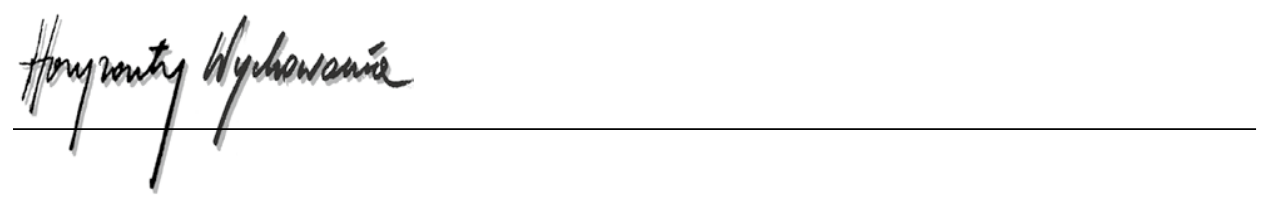

Media i rodzinę - podkreślmy jeszcze raz - łączy pewien rodzaj komunikacyjnego pokrewieństwa. Franciszek w orędziu na Światowy Dzień Komunikacji Społecznej w 2015 r. pisał:

Rodzina jest (...) pierwszym miejscem, gdzie uczymy się komunikowania, powrót do tego autentycznego momentu może nam pomóc zarówno w uczynieniu komunikacji (la comunicazione $)^{9}$ bardziej ludzką, jak i w postrzeganiu rodziny z nowego punktu widzenia. (...) To w rodzinie uczymy się mówić [...] w języku naszych przodków (...). W rodzinie dostrzegamy, że inni byli przed nami, sprawili, że zaistnieliśmy i możemy z kolei rodzić życie oraz czynić coś dobrego i pięknego. Możemy dawać, ponieważ otrzymaliśmy, a to pozytywne sprzężenie zwrotne stoi u podstaw zdolności rodziny do komunikowania się między sobą i komunikowania innym: bardziej ogólnie, [rodzina] jest modelem każdej komunikacji (il paradigma di ogni comunicazione) (Franciszek, 2015).

Z dotychczasowego nauczania Franciszka o środkach komunikacji społecznej i rodzinie wynika, że media nie tyle są źródłem kryzysu rodziny, ile poświadczają jego istnienie, a przy tym czynią to jednostronnie, skupiając się na kryzysowej sytuacji rodziny. Nie znaczy to jednak, że media, środki komunikacji społecznej, nie mogą być problemem, zagrożeniem, niebezpieczeństwem dla rodziny. Papież, mając na uwadze Internet, social media i telefon komórkowy, mówił (w duchu hermeneutyki optymizmu krytycznego) w 2018 r. do rodzin w Filadelfii:

media społecznościowe nie muszą koniecznie stanowić problemu dla rodzin, ale mogą dopomóc zbudować „sieć” przyjaźni, solidarności i wzajemnego wsparcia. Rodziny mogą się łączyć się poprzez Internet, i z niego korzystać. Media społecznościowe mogą być pożyteczne, jeśli są używane umiarkowanie i roztropnie. (...) Ważne jest jednak, aby te środki nigdy nie stały się zagrożeniem dla prawdziwej sieci relacji z krwi i ciała, zniewalając nas

została dokonana w kolejnym wydaniu z roku 2002. Jeszcze poważniejszym błędem tegoż wydania jest usunięcie wprowadzenia ks. Andrzeja Marii Deskura i zastąpienie go wstępem autorstwa ks. biskupa Adama Lepy, który usprawiedliwia fakt odejścia od wierności tłumaczenia... «terminologią powszechnie przyjętą [sic!] w języku polskim». Oznacza to zafałszowanie idei soborowej nie tylko w sferze werbalnej, ale - co gorsza - rezygnację Kościoła w Polsce, w debacie o mediach, $z$ istotnego argumentu. Na tle negatywnych zjawisk widocznych na medialnym horyzoncie jest to co potwierdza praktyka - utrata pola tematycznego o fundamentalnym znaczeniu" (Dobroczyński, 2013, s. 557; cytat wypowiedzi bp. Lepy w: Lepa, 2002, s. 81, przypis 1).

${ }^{9} \mathrm{~W}$ tym miejscu poprawiam oficjalne polskie tłumaczenie tego dokumentu, które włoskie, oryginalne la comunicazione oddaje przez „przekaz”. Ten sam błąd konsekwentnie pojawia się w oficjalnych i nieoficjalnych (nie tylko) polskich przekładach innych "medialno-komunikacyjnych” dokumentów kościelnych lub nazw instytucji, nawet w przekładach znajdujących się na oficjalnej stronie Watykanu! W polskich przekładach Giornata Mondiale delle Comunicazioni Sociali to niestety „Światowy Dzień Środków Społecznego Przekazu”, a nie - jak głosi nazwa oryginalna - „Światowy Dzień Komunikacji Społecznej”. Podobnie dzieje się z nazwą watykańskiej rady zajmującej się mediami: Pontificio Consiglio delle Comunicazioni Sociali okazuje się nie „Papieską Radą Komunikacji Społecznej”, ale „Papieską Radą ds. Środków Społecznego Przekazu (od 2018 r. Dykasteria ds. Komunikacji). Zasadniczo konsekwentnie „przekazowo”, nie zaś „komunikacyjnie” tłumaczy się również medialne dokumenty kościelne, w tym orędzia Franciszka na Giornata Mondiale delle Comunicazioni Sociali. Przykład: orędzie z 2014 r. w oryginale nosi tytuł Comunicazione al servizio di un'autentica cultura dell'incontro, a w oficjalnym polskim tłumaczeniu Przekaz w służbie autentycznej kultury spotkania. 
w wirtualnej rzeczywistości i odizolowując od autentycznych relacji, które pobudzają nas do tego, aby dawać z siebie to, co najlepsze w komunii z innymi. (...) Ale kiedy nazbyt używasz mediów społecznościowych jesteś «na orbicie». Kiedy przy stole, zamiast rozmawiać w rodzinie, każdy ma telefon komórkowy [przed soba]], to jest „na orbicie”. To niebezpieczne, bo wyrywa ciebie z konkretnego życia rodziny i porywa ku życiu odlotowemu, bez konsystencji. Uważajcie na to! (Franciszek, 2018).

Media mogą być problemem czy zagrożeniem dla rodziny, ale mogą także dobrze służyć rodzinie. Dobrze jej służą zarówno wtedy, gdy świadczą o tym, „że rodzina jest nadal wielkim bogactwem, a nie tylko problemem lub instytucją przeżywającą kryzys" (Franciszek 2015), jak też (i przede wszystkim) wtedy, gdy właściwie realizują swoją misję, tj. gdy dobrze komunikując, służą komunikacji między ludźmi, tak jak w rodzinie „modelu każdej komunikacji”. A podstawowym celem komunikowania nie jest tylko przekaz informacji czy rozrywka, celem komunikacji nie może być także wyłącznie konsumpcja, tym bardziej manipulacja osobami, ale służba - jak ujmuje to papież - „autentycznej kulturze spotkania" (Franciszek, 2014). Wszystkie dotychczasowe orędzia Franciszka na Światowy Dzień Komunikacji Społecznej w istocie są - jak sądzę - medytacjami właśnie nad tą kultury i jej charakterystyką (Franciszek, 2014-2019).

W autentycznej kulturze spotkania chodzi o komunię osób: „W Bożym zamyśle ludzka komunikacja jest istotnym sposobem, aby żyć w komunii” (Franciszek, 2018b). Taki jest cel zarówno rodziny, jak i mediów, środków komunikacji społecznej. Natomiast komunia wymaga przede wszystkim - jak stale podkreśla Franciszek - bliskości, bo „bliskość (...) otacza troską, pociesza, uzdrawia, towarzyszy i wyprawia święto”. Autentyczna kultura spotkania domaga się czułości, wspierania się i towarzyszenia sobie, dialogu i prawdy, przebaczenia i milczenia. Jest nie do pomyślenia bez odpowiedzialności za drugiego. Komunia domaga się słuchania, ale samo słuchanie nie wystarcza - konieczne jest wysłuchanie, które „nigdy nie jest łatwe”:

Wysłuchanie to znacznie więcej niż słuchanie („Ascoltare è molto più che udire”). Słuchanie dotyczy dziedziny informacji; natomiast wysłuchanie odwołuje się do komunikacji i wymaga bliskości

oraz

oznacza również zdolność dzielenia się pytaniami i wątpliwościami, przemierzenie jakiejś drogi obok siebie, wyzwolenie się z wszelkiej pyszałkowatości wszechmocy i pokorne oddanie swoich umiejętności i darów na służbę dobra wspólnego (Franciszek, 2014-2019).

Papież przekonuje, że media, Internet czy sieci społecznościowe osiągają swój podstawowy cel, gdy dopełniają

spotkanie osobowe ${ }^{10}$, które przeżywa się poprzez ciało, serce, oczy, spojrzenie, oddech drugiego. Jeśli sieć [komunikacja wirtualna] jest używana jako przedłużenie lub jako

${ }^{10}$ Poprawiam przekład polski, który w tym miejscu ma postać: „dopełnia spotkania osobowego”. 


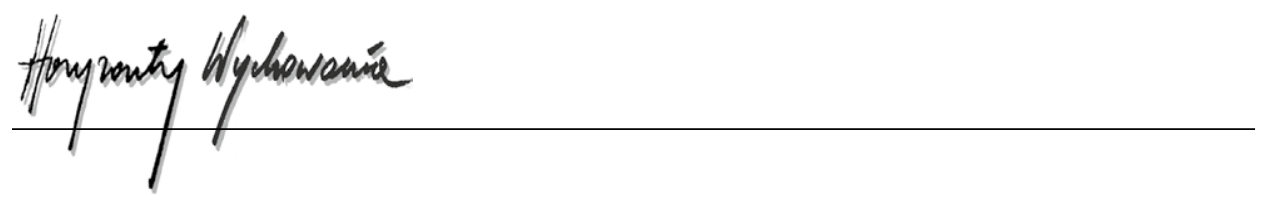

oczekiwanie na to spotkanie, to wówczas nie zdradza siebie i pozostaje bogactwem dla komunii. Jeśli rodzina korzysta z sieci, aby być bardziej powiązana ze sobą, aby następnie spotkać się przy stole i spojrzeć sobie w oczy, to jest to bogactwo. (...). Jeśli sieć jest szansą, by przybliżyć mnie do dziejów i doświadczeń piękna lub cierpienia fizycznie dalekich ode mnie, do wspólnej modlitwy i szukania dobra w ponownym odkryciu tego, co nas łączy, to jest to bogactwo (Franciszek, 2019).

\section{Zakończenie}

Powtórzmy: Franciszek w spojrzeniu na współczesny kryzys rodziny i jego relację do mediatyzacji życia społecznego wypowiada się ostrożnie, posługując się językiem wyważonym. Raczej - w duchu hermeneutyki optymizmu krytycznego - nie widzi w rewolucji technologiczno-medialnej i funkcjonowaniu środków komunikacji społecznej źródła kryzysu rodziny, ale sugeruje, że współczesne media mogą temu kryzysowi służyć mogą stawiać rodzinę przed poważnymi problemami i zagrożeniami. Pogląd ten wyraźnie przedstawił w adhortacji Amoris laetitia o miłości w rodzinie. Nieco dłuższą wypowiedzią z tego dokumentu, noszącą znamiona podsumowania niniejszych analiz, wypada zakończyć te rozważania:

Spotkanie edukacyjne między rodzicami a dziećmi może być ułatwione lub utrudnione przez coraz bardziej zaawansowane technologie komunikacji i rozrywki. Kiedy są one dobrze używane, mogą pomagać w łączeniu członków rodziny pomimo odległości. Kontakty mogą być częste i pomagać w rozwiązywaniu trudności. Jednak musi być jasne, że nie zastępują one potrzeby dialogu bardziej osobistego i głębokiego, który wymaga kontaktu fizycznego, albo przynajmniej usłyszenia głosu drugiej osoby. Wiemy, że czasami te środki oddalają, a nie zbliżają, jak na przykład, kiedy w porze posiłku każdy zajmuje się swoim telefonem komórkowym lub kiedy jedno z małżonków zasypia czekając na drugiego, który spędza całe godziny przy jakimś urządzeniu elektronicznym. Także i to powinno być przedmiotem dialogu i porozumień w rodzinie, dających pierwszeństwo spotkaniu jej członków bez popadania w nieracjonalne zakazy. Nie można jednak ignorować zagrożenia nowych form komunikacji dla dzieci i młodzieży, które czasem stają się bezwolne, wyrwane z realnego świata. Ten „autyzm technologiczny” łatwiej naraża je na manipulacje tych, którzy chcą wejść w głębię ich życia z egoistycznymi interesami (Franciszek, 2016b, nr 278).

\section{BIBLIOGRAFIA}

Bawin-Legros, B. (2001). Families in Europe: A Private and Political Stake - Intimacy and Solidarity. Current Sociology, 5, 49-65.

Deskur, A.M. (1968). Wprowadzenie do Dekretu o środkach społecznego przekazywania myśli. W: Sobór Watykański II. Konstytucje, dekrety, deklaracje. Tekst polski. Poznań: Wydawnictwo Pallotinum, 73-77.

Dobroczyński, G. (2013). Kościół Web 2.0 w matni czy w sieci? W: M. Białkowski (red.), Studia soborowe. Historia i nauczanie Vaticanum II. Toruń: Oficyna Wydawnicza Finna, 547-583.

Driessens, O., Bolin, G., Hepp, A. i Hjarvard, S. (red.). (2017). Dynamics of Mediatization. Institutional Change and Everyday Transformations in a Digital Age. London: Palgrave Macmillan. 
Drożdż, M. i Smoleń, J. (red.). (2015). Mediatyzacja życia: zjawisko i konteksty. Zeszyty Prasoznawcze, 1 (numer monograficzny).

Eilers, F.-J. (1993). Introduction. W: F.-J. Eilers (red. i wstęp), Church and Social Communication: Basic Documents. Manila: Logos Publication, 57.

Eilers, F.-J. (2016). „Go and Proclaim” (Mk 16:15). Mission and Social Communication in a New Culture for Evangelisation. W: J. Kavunkal i Ch. Tauchner (red.), Mission Beyond „Ad Gentes”. A Symposium. Siegburg: Franz Schmitt Verlag, 103-110.

Franciszek (2013a). Esortazione apostolica „Evangelii gaudium” ai vescovi ai presbiteri e ai diaconi alle persone consacrate e ai fedeli laici sull' annuncio del Vangelo nel mondo attuale. Pozyskano z: https://ekai.pl/swiatowe-spotkanie-rodzin-zakonczone-eucharystia/ (dostęp: 13.11.2019).

Franciszek (2013b). Adhortacja apostolska „Evangelii gaudium”. Pozyskano z: https://opoka.org. pl/biblioteka/W/WP/franciszek_i/adhortacje/evangelii-w2_24112013.html (dostęp: 13.11.2019).

Franciszek (2014-2019). Orędzia na: 48. Dzień Środków Komunikacji Społecznej „Przekaz w służbie autentycznej kultury spotkania”. Pozyskano z: http://w2.vatican.va/content/francesco/pl/ messages/communications/documents/papa-francesco_20140124_messaggio-comunicazioni-sociali.html (dostęp: 12.11.2019); 49. Dzień Środków Komunikacji Społecznej „Komunikacja rodziny: uprzywilejowane środowisko spotkania w bezinteresownej miłości”. Pozyskano z: http://w2.vatican.va/content/francesco/pl/messages/communications/documents/papa-francesco_20150123_messaggio-comunicazioni-sociali.html (dostęp: 12.11.2019); 50. Dzień Środków Komunikacji Społecznej „Komunikacja i miłosierdzie - owocne spotkanie”. Pozyskano z: http://w2.vatican.va/content/francesco/it/messages/communications/documents/papa-francesco_20160124_messaggio-comunicazioni-sociali.html (dostęp: 12.11.2019); 51. Światowy Dzień Środków Komunikacji Społecznej „ "Nie lękaj się, bo jestem z tobą» (Iz 43, 5). Komunikujemy nadzieję i ufność w naszych czasach". Pozyskano z: http://w2.vatican.va/content/ francesco/it/messages/communications/documents/papa-francesco_20170124_messaggio-comunicazioni-sociali.html (dostęp: 12.11.2019); 52. Światowy Dzień Środków Komunikacji Społecznej „ «Prawda was wyzwoli» $(J$ 8, 32). Fake news a dziennikarstwo pokoju”. Pozyskano z: http://w2.vatican.va/content/francesco/it/messages/communications/documents/papa-francesco_20180124_messaggio-comunicazioni-sociali.html (dostęp: 12.11.2019); 53. Światowy Dzień Środków Społecznego Przekazu, „ «Wszyscy tworzymy jedno» (Ef 4, 25). Od wirtualnych wspólnot społecznościowych do wspólnot ludzkich". Pozyskano z: http://w2.vatican.va/content/ francesco/it/messages/communications/documents/papa-francesco_20190124_messaggio-comunicazioni-sociali.html (dostęp: 12.11.2019).

Franciszek (2015). Orędzie na 49. Światowy Dzień Komunikacji Społecznej „Komunikacja rodziny: uprzywilejowane środowisko spotkania w bezinteresownej miłości”. Pozyskano z: http:// w2.vatican.va/content/francesco/pl/messages/communications/documents/papa-francesco_20150123_messaggio-comunicazioni-sociali.html (dostęp: 12.11.2019).

Franciszek (2016a). Adhortatio apostolica post-synodalis „Amoris laetitia” episcopis presbyteris diaconis ersonis consecratis christianis coniugibus omnibus christifidelibusde amore in familia. Pozyskano z: http://w2.vatican.va/content/francesco/la/apost_exhortations/documents/papa-francesco_esortazione-ap_20160319_amoris-laetitia.html (dostęp: 04.11.2019).

Franciszek (2016b). Posynodalna adhortacja apostolska „Amoris laetitia” o miłości i rodzinie. Pozyskano z: http://www.vatican.va/content/francesco/pl/apost_exhortations/documents/papa-francesco_esortazione-ap_20160319_amoris-laetitia.html (dostęp: 04.11.2019).

Franciszek (2017). Discorso ai capi di stato e di governo dell'Unione Europea, in occasione del $60^{\circ}$ anniversario della firma dei trattati di Roma. Pozyskano z: http://w2.vatican.va/content/francesco/pl/speeches/2017/march/documents/papa-francesco_20170324_capi-unione-europea. html (dostęp: 09.11.2019). 


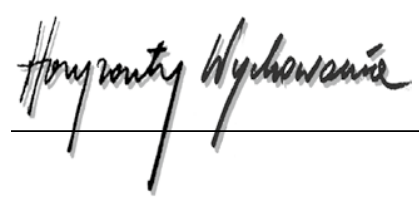

Franciszek (2018a). Świętowanie z rodzinami, Dublin, Stadion Croke Park, 25 sierpnia 2018 r. Pozyskano z: http://w2.vatican.va/content/francesco/pl/speeches/2018/august/documents/papa-francesco_20180825_dublino-irlanda-festafamiglie.html (dostęp: 09.11.2019).

Franciszek (2018b). Orędzie na 52. Światowy Dzień Komunikacji Społecznej „ „Prawda was wyzwoli» (J 8,32). Fake news a dziennikarstwo pokoju". Pozyskano z: http://w2.vatican.va/content/ francesco/it/messages/communications/documents/papa-francesco_20180124_messaggio-comunicazioni-sociali.html (dostęp: 12.11.2019).

Gielarowski, A. (2016). Kryzys kultury, kryzys człowieka. Fenomenologiczna krytyka kultury: Husserl, Lévinas, Henry. Kraków: Akademia Ignatianum w Krakowie, Wydawnictwo WAM.

Hjarvard, S. (2013). The Mediatization of Culture and Society. New York: Routledge.

Husserl, E. (1993). Kryzys europejskiego człowieczeństwa a filozofia. Warszawa: Aletheia.

Kasper, W. (2001). Present Situation and Future of the Ecumenical Movement. Pozyskano z: http://www.vatican.va/roman_curia/pontifical_councils/chrstuni/documents/rc_pc_chrstuni_ doc_20011117_kasper-prolusio_en.html (dostęp: 12.11.2019).

Kasper, W. (2003). Ecumenism: the Way Ahead. The Tablet, 24 maja, 32-25.

Kawula, S. (2006). Kształty rodziny współczesnej. Szkice femiologiczne. Toruń: Wydawnictwo Adam Marszałek.

Kocik, L. (2006). Rodzina w obliczu wartości i wzorów ponowoczesnego świata. Kraków: Krakowskie Towarzystwo Edukacyjne - Oficyna Wydawnicza AFM.

Koselleck, R. (2006). Crisis. Journal of the History of Ideas, 2, 357-400.

Koselleck, R. (2015). Krytyka i kryzys. Studium patogenezy świata mieszczańskiego. Przekład, wstęp i opracowanie J. Duraj, M. Moskalewicz, redakcja naukowa M. Moskalewicz. Warszawa: Biblioteka Res Publiki Nowej.

Lepa, A. (2002). Wprowadzenie do Dekretu o środkach społecznego przekazu. W: Sobór Watykański Il. Konstytucje, dekrety, deklaracja. Tekst polski, nowe tłumaczenie. Poznań: Pallotinum, 81-86.

Levinson, P. (2010). Nowe nowe media. Przeł. M. Zawadzka. Kraków: Wydawnictwo WAM.

Lisowska-Magdziarz, M. (red.). (2015). Mediatyzacja kultury i życia społecznego. Zeszyty Prasoznawcze, 3 (numer monograficzny).

Mencwel, A. (2012). Przyczyniać się pomału. W: G. Godlewski, I. Kurz, A. Mencwel i M. Wójtowski (red.), Animacja kultury. Doświadczenie i przyszłość. Warszawa: Instytut Kultury Polskiej Uniwersytet Warszawski.

Skuczyński, P. (2018). Pojęcie kryzysu w filozofii i naukach społecznych a kryzysy prawne. Filozofia Publiczna i Edukacja Demokratyczna, 1, 250-275.

Sobór Watykański II (1963). Decretum de instrumentis communicationis socialis "Inter mirifica”. Pozyskano z: http://www.vatican.va/archive/hist_councils/ii_vatican_council/documents/vat-ii_ decree_19631204_inter-mirifica_It.html (dostęp: 04.11.2019).

Sobór Watykański II (1968). Dekret o środkach społecznego przekazywania myśli „Inter mirifica”. W: Konstytucje, dekrety, deklaracje. Tekst polski. Poznań: Wydawnictwo Pallotinum

Sobór Watykański II (2002). Dekret o środkach społecznego przekazu „Inter mirifica”. W: Konstytucje, dekrety, deklaracje. Tekst polski, nowe tłumaczenie. Poznań: Pallotinum

Szlendak, T. (2010). Socjologia rodziny. Ewolucja, historia, zróżnicowanie. Warszawa: Wydawnictwo Naukowe PWN.

Treas, J., Scott, J. i Richards, M. (red.). (2017). The Sociology of Families. Oxford: Wiley Blackwell.

\section{Copyright and License}

This article is published under the terms of the Creative Commons Attribution - NoDerivs (CC BY- ND 4.0) License http://creativecommons.org/licenses/by-nd/4.0/ 